\title{
THE ELECTROOXIDATION OF CHEMISORBED CO ON POLYCRYSTALLINE PLATINUM
}

\section{A MECHANISTIC INTERPRETATION OF THE ANODIC CURRENT PEAK MULTIPLICITY}

\author{
S A BILMES, N R. DE TACCONI and A J ARVIA \\ Instituto de Investigaciones Fisicoquímicas Teóricas y Aplicadas (INIFTA), Castlla de Correo 16, Sucursal 4, \\ 1900 - La Plata (Argentına)
}

(Received 22nd February 1983, in final form 28th October 1983)

\begin{abstract}
The electrooxidation of $\mathrm{CO}$ on polycrystallıne $\mathrm{Pt}$ in $1 \mathrm{M} \mathrm{HClO}_{4}$ at $23^{\circ} \mathrm{C}$ under potentiodynamic conditions exhibits a double current peak Whether a single or a double current peak is formed depends to a great extent on the amount of $\mathrm{CO}$ surface coverage. The present report attempts to explain the behaviour of the electrochemical reaction in terms of a single model involving the participation of two $\mathrm{CO}$ adsorbed states on polycrystallıne Pt.
\end{abstract}

\section{INTRODUCTION}

The electrocatalytic oxidation of $\mathrm{CO}$ using noble metals involves a complex reaction pattern which depends to a great extent on the composition and physicochemical characteristics of the electrocatalyst used. Most of the kinetic problems related to this reaction have been reviewed in refs. 1-3.

Despite the differences between the platinum $/ \mathrm{CO}(\mathrm{g})$ and the platinum/electrolyte (aq.) $/ \mathrm{CO}(\mathrm{g})$ interfaces, common structural features related to the adsorption of $\mathrm{CO}$ in the former system may be applied to the interpretation of the electrocatalytic oxidation of $\mathrm{CO}$ on platinum. The adsorption data of $\mathrm{CO}$ from the gaseous phase on platinum have been derived from different techniques, such as IR spectroscopy [4], electron energy loss spectroscopy [5] and thermal desorption [6], which indicate the existence of at least two different adsorbed states of $\mathrm{CO}$ on platinum which are assigned to the linear and bridged $\mathrm{CO}$ forms. The adsorption of gaseous $\mathrm{CO}$ in the linear form on platinum at low surface coverage $\left(\theta_{\mathrm{CO}}<0.3\right)$ and as a $1: 1$ mixture of linear and bridged $\mathrm{CO}\left(\right.$ at $\left.\theta_{\mathrm{CO}} \approx 0.5\right)$ has been reported [7].

On the other hand, the electrocatalytic oxidation of $\mathrm{CO}$ on polycrystalline platinum electrodes [8] reveals through the corresponding potentiodynamic $E / I$ profile a complex electrooxidation reaction involving the participation of various 
surface species whose coverage distribution and electrochemical characteristics are very strongly dependent on the extent of oxidation and on the type of O-contanning species remaining on the electrode surface. These processes are also influenced by the adsorption of anions in solution in two main directions namely through the inhibition effect which lags the initiation of $\mathrm{OH}$ - and O-submonolayer formation [9], and through the ageing of both the electrocatalyst [10] and the O-containing layer formed on it [11]. The latter alters the overall characteristics of the remaining O-layer on platinum. These results suggest that two types of $\mathrm{CO}$-adsorbed species also participate in the electrooxidation of $\mathrm{CO}$ at polycrystalline platinum in different potential ranges [12-17], but a conversion of one adsorption form to another, which might be suspected if one form appeared to be oxidized to the exclusion of the other, was apparently excluded [15].

The effect of chemisorbed $\mathrm{CO}$ on the cathodic evolution and anodic oxidation of molecular hydrogen, and on the cathodic reduction of molecular oxygen on smooth platınum in acid was also studied [18-20] in relation to a possible change in the mechanism of the electrooxidation of adsorbed $\mathrm{CO}$.

The present paper deals with a mechanistic interpretation of the anodic current peak multiplicity related to the electrooxidation of $\mathrm{CO}$ on polycrystalline platinum in acid electrolytes. Recent electrochemically-modulated IR spectroscopy data on the adsorption of $\mathrm{CO}$ on platinum electrodes in $\mathrm{H}_{2} \mathrm{SO}_{4}$ solution support, in principle, the existence of two forms of adsorbed $\mathrm{CO}$ [21,22], although for polycrystalline platinum it was assumed that was $\mathrm{CO}$ adsorbed in a random manner so that the adsorbed layer would probably show a behaviour which was an average of the behaviour of $\mathrm{CO}$ on the different crystal surfaces [23]. The existence of electrochemically-distınguishable adsorption states for $\mathrm{CO}$ on polycrystalline platinum may offer the possibility that position-exchange surface reactions involving the different species occur. This reaction should be reflected through the potentiodynamic electrooxidation of the adsorbed species under perturbation conditions whereby the re-adsorption of $\mathrm{CO}$ is carefully avoided.

\section{EXPERIMENTAL}

The experiments were run at $23^{\circ} \mathrm{C}$ using a conventional three-compartment Pyrex glass electrolysis cell and polycrystalline, spectroscopically-pure, smooth platinum wire electrodes of apparent areas in the order of $0.25 \mathrm{~cm}^{2}$. The counter electrode was also made of platinum. The potential of the working electrode was measured against a reversible hydrogen electrode in the electrolyte solution.

A $1 M \mathrm{HClO}_{4}$ solution made from carefully distilled water [24] and Suprapure (Merck) $70 \% \mathrm{HClO}_{4}$ was employed as electrolyte. It was saturated at a pressure of 1 atm with CO. Pretreatment of the working electrode consisted of potential cycling in the electrolyte with a repetitive symmetric triangular perturbation at $10 \mathrm{v} / \mathrm{s}$ in the $-0.02-1.35 \mathrm{~V}$ range to avoid the adsorption of $\mathrm{CO}$ on the electrode surface. For the purpose, a waiting time was included in the potential/time $(E / t)$ perturbation programme during the sweep of the negative potential to reach the pre-selected 
adsorption potential $\left(E_{\mathrm{ad}}\right)$. In this way the platınum surface was cleaned of $\mathrm{CO}$. Depending on the value of $E_{\text {ad }}$, the surface may contain traces of $\mathrm{O}$ - or $\mathrm{H}$-species at the intial stage of $\mathrm{CO}$ adsorption at $E_{\mathrm{ad}}$. This procedure brought the surface to a reproducible state for the adsorption of $\mathrm{CO}$.

\section{RESULTS}

The conventional potential/current $(E / I)$ profile recorded after holding the electrode at open circuit for $20 \mathrm{~min}$ in the $\mathrm{CO}$-saturated electrolyte at 1 atm pressure (Fig. 1) exhibits the anodic and cathodic current peaks related to the $\mathrm{H}$-adatoms in the $0.04-0.35 \mathrm{~V}$ range and the cathodic current peak related to the electroreduction of the $O$-containing surface species in the $0.52-1.00 \mathrm{~V}$ range in agreement with earlier reported results [25-28]. A large and relatively sharp anodic current peak recorded in the $0.82-1.04 \mathrm{~V}$ range is associated with the electrooxidation of $\mathrm{CO}$. This peak overlaps the initial electrosorption current of the O-containing species.

To minimize any interference of $\mathrm{CO}$ re-adsorption from the solution, the potentiodynamic $E / I$ profiles were recorded after holding the pretreated platinum

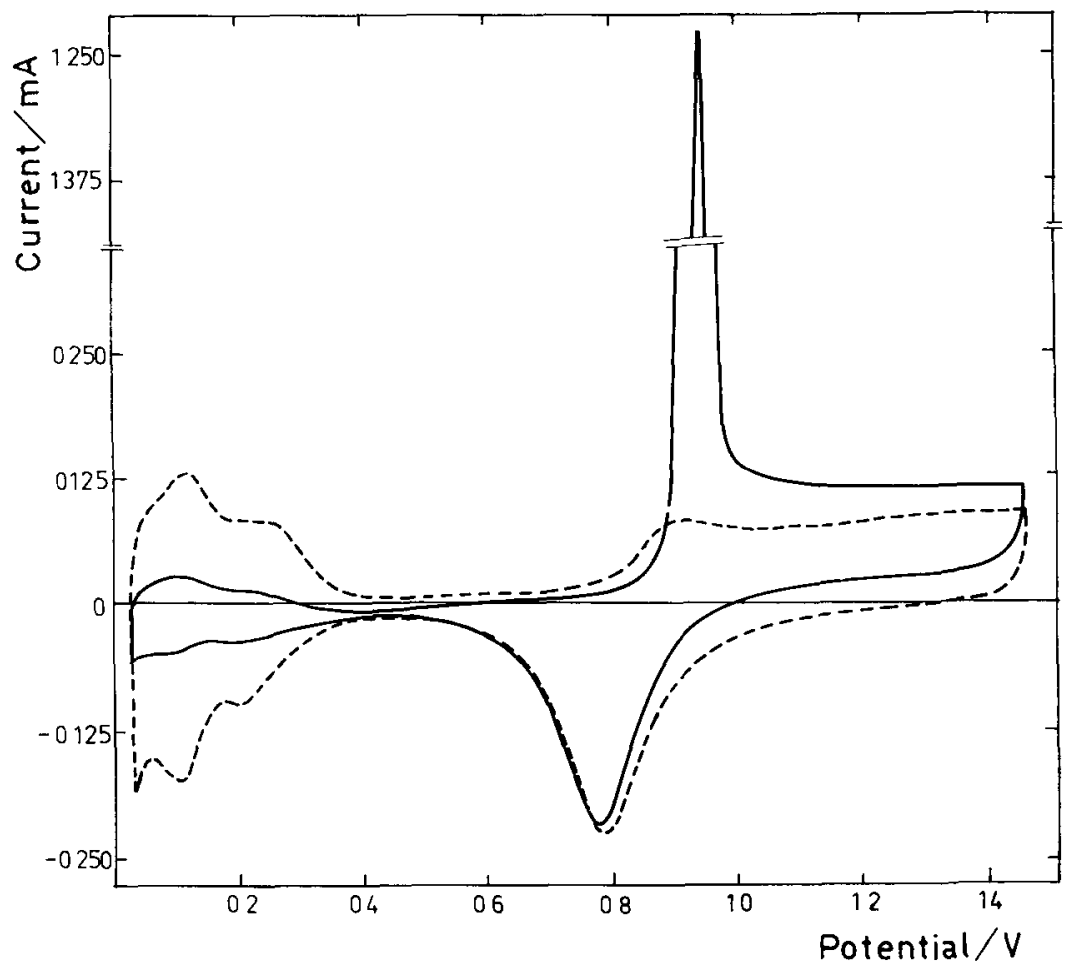

Fig 1 Potentiodynamic $E / I$ profiles of platinum in $1 M \mathrm{HClO}_{4}$ run at $0.1 \mathrm{~V} / \mathrm{s}$ at $25^{\circ} \mathrm{C}$. (-- $\mathrm{CO}(1$ atm) saturated solution; (- - - ) $\mathrm{N}_{2}$ saturated solution. 
electrode at a fixed potential $\left(E_{\mathrm{ad}}\right)$ for the time $\left(t_{\mathrm{ad}}\right)$ taken to produce a certain coverage of the electrocatalyst surface with adsorbed $\mathrm{CO}$ species, and afterwards applying the triangular potential scan at $10 \mathrm{~V} / \mathrm{s}$ from $E_{\mathrm{ad}}$ towards $E_{\mathrm{s}, \mathrm{c}}$ covering the $\mathrm{H}$-adatom potential range. $E_{\text {ad }}$ was set in the potential range of the double layer, charging and discharging as observed in the $E / I$ profile run with the blank under repetitive triangular potential sweeps (RTPS). In these experıments the double-layer charging current for $\mathrm{CO}$-covered platinum decreases proportionally to the $\mathrm{CO}$ coverage, reaching a charging current of approximately one-half of that corresponding to bare platinum [29]. The anodic $E / I$ profile, which is strongly dependent on $t_{\text {ad }}$ (Fig. 2), shows two current peaks, I and II, associated with the electrooxidation of $\mathrm{CO}$-adsorbed species located in the $0.8-1.1 \mathrm{~V}$ range, just inside the $\mathrm{O}$-electrosorption potential range.

The $E / I$ displays show competition for adsorption sites between the $\mathrm{H}$-adatoms and the $\mathrm{CO}$ species. As $t_{\mathrm{ad}}$ increases, both the anodic and the cathodic charges

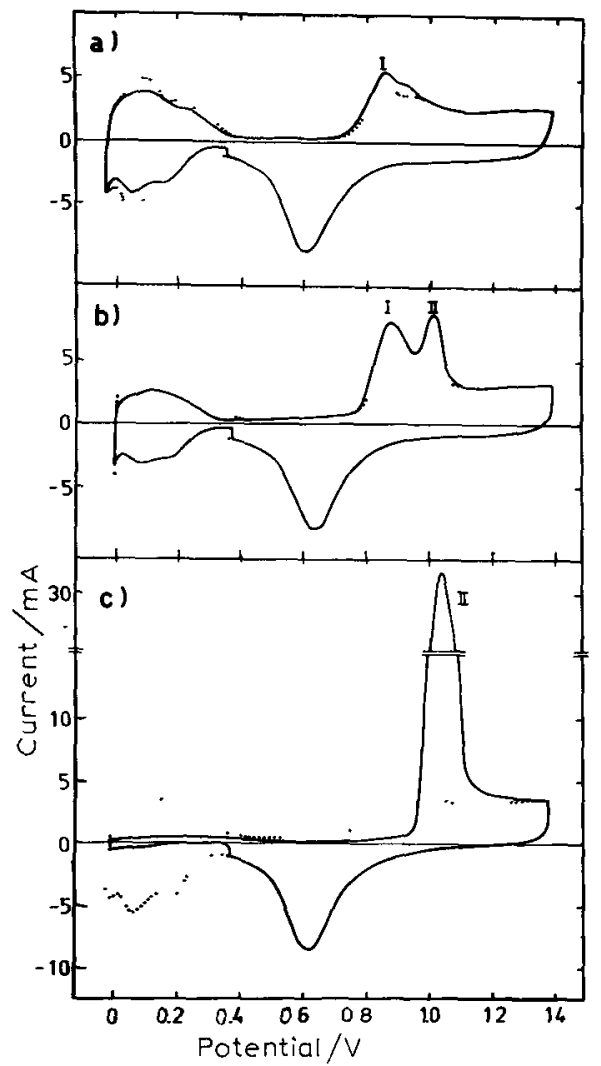

Fig 2. Voltammograms run at $10 \mathrm{~V} / \mathrm{s}$ after $\mathrm{CO}$ adsorption at $E_{\mathrm{ad}}=0.39 \mathrm{~V}$ during different values of $t_{\mathrm{ad}}$. (a) $t_{\mathrm{ad}}=0.11 \mathrm{~s}$; (b) $t_{\mathrm{ad}}=11 \mathrm{~s}$; (c) $t_{\mathrm{ad}}=11 \mathrm{~s} ;(\cdot \cdots) t_{\mathrm{ad}}=0 \mathrm{~s}$. 
related to the $\mathrm{H}$-adatoms decrease and simultaneously the anodic charge related to the electrooxidation of the adsorbed $\mathrm{CO}$ increases. Hence, $\mathrm{CO}$ adsorbed at $E_{\mathrm{ad}}$ inhibits the electrosorption of $\mathrm{H}$-adatoms. On the other hand, the greatest enhancement of anodic peak multiplicity is apparently noticed when the degree of surface coverage $(\theta)$ is ca. 0.3 . Thus, when only a small fraction of the surface is covered by $\mathrm{CO}\left(t_{\mathrm{ad}} \rightarrow 0\right)$, peak I located at ca. $0.85 \mathrm{~V}$ prevails. In this case, peak II is centred at ca. $1.05 \mathrm{~V}$. Conversely, when $\theta_{\mathrm{CO}} \rightarrow 1\left(t_{\mathrm{ad}} \rightarrow \infty\right)$, peak II only is exhibited in accord with the data reported in the literature $[8,28]$. The contribution of peak I reaches a maximum value at ca. $2 \mathrm{~s}$ (F1g. 3) and then decreases, approaching zero, while that of peak II intially increases linearly with $t_{\mathrm{ad}}$ and, at large $t_{\mathrm{ad}}$, attains a limiting value.

After $\mathrm{CO}$ adsorption, the anodic profile run at $10 \mathrm{~V} / \mathrm{s}$ is independent of the direction of the potential sweep in the $E_{\mathrm{s}, a}$ range $-0.02-1.20 \mathrm{~V}$ [30]. This confirms that practically no $\mathrm{CO}$ reduction is observed in the course of the H-adatom electrosorption reaction [13] and agrees with the most recent data from mass-spectrometric voltammetry related to the electrooxidation of $\mathrm{CO}$ on Pt electrodes [31]. Therefore, as previously suggested [32], the $\mathrm{H}-\mathrm{CO}$ interactions are apparently repulsive above $0.15 \mathrm{~V}$ (RHE), and no net interactions occur for $E<0.15 \mathrm{~V}$ [32].

The anodic charge $\left(Q_{\mathrm{A}}\right)$ obtained from the $E / I$ profile run immediately after holding the potential at $E_{\text {ad }}$ during $t_{\text {ad }}$ involves the charge related to the electrooxidation of adsorbed $\mathrm{CO}\left(Q_{\mathrm{CO}}^{\mathrm{T}}\right)$ and the $\mathrm{O}$-electroadsorption charge $\left(Q_{\mathrm{OX}}\right)$ :

$Q_{\mathrm{A}}=Q_{\mathrm{CO}}^{\mathrm{T}}+Q_{\mathrm{ox}}$

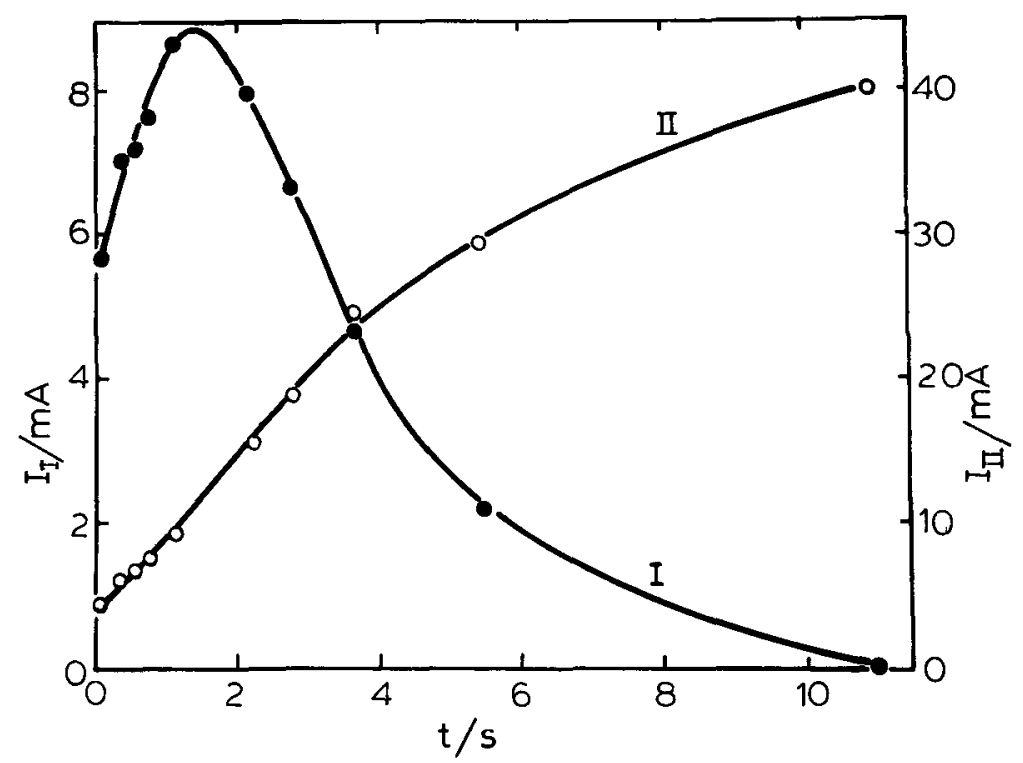

Fig 3 Dependence of the anodic current peak heights on $t_{\text {ad }}$ (๑) Peak I; (O) peak II Data obtained from voltammograms run as indicated in Fig 2 
As the O-electrodesorption charge is independent of $t_{\mathrm{ad}}, Q_{\mathrm{Ox}}$ can be estimated as the value of $Q_{\mathrm{A}}$ when $t_{\text {ad }} \rightarrow 0\left(Q_{\mathrm{A}}^{\circ}\right)$, thence:

$Q_{\mathrm{CO}}^{\mathrm{T}}=Q_{\mathrm{A}}-Q_{\mathrm{A}}^{\circ}$

On the other hand, the charge related to the H-adatoms $\left(Q_{\mathrm{H}}\right)$ was obtained from the anodic profile [33,34] in the $0.0-0.45 \mathrm{~V}$ range instead of the cathodic profile [17], by taking $210 \mu \mathrm{C} / \mathrm{cm}^{2}$ as the charge of the $\mathrm{H}$-adatom monolayer on polycrystalline platinum [35].

\section{INTERPRETATION AND DISCUSSION}

The multiplicity of current peaks related to the electrooxidation of adsorbed CO indicates the existence of at least two energetically-distinguishable $\mathrm{CO}$ reactant species on polycrystalline platinum. By analogy with the results obtained from the $\mathrm{CO}$ adsorption from the gaseous phase on platınum [36], one may assume that the two different $\mathrm{CO}$ species formed on the platinum surface are one with a bridge-type structure (B) involving two adjacent adsorption sites, and the other with a linear structure (L) corresponding to one adsorption site per $\mathrm{CO}$-adsorbed particle.

The CO-adsorbed structure related to peak I apparently prevails when $t_{\text {ad }} \rightarrow 0$. In this case, the $\mathrm{H}$-adatom electrodesorption charge $\left(Q_{\mathrm{H}}^{\circ}\right)$ for $t_{\mathrm{ad}}=0$ can be expressed as

$Q_{\mathrm{H}}^{\circ} \approx Q_{\mathrm{H}}+Q_{\mathrm{CO}}^{\mathrm{T}}$

Otherwise, when $t_{\mathrm{ad}} \rightarrow \infty$, only the CO-adsorbed structure associated with peak II is observed so that

$2 Q_{\mathrm{H}}^{\circ} \approx Q_{\mathrm{CO}}^{\mathrm{T}}$

The balance equations (3) and (4) are consistent with the assumption that peaks I and II are related to the bridged-CO and to the linear-CO structure, respectively. In the former case, the electrooxidation involves one electron per adsorption site while in the latter two electrons per adsorption site are required. The degree of surface coverage of each adsorbed species can be calculated from $Q_{\mathrm{CO}}^{\mathrm{T}}, Q_{\mathrm{H}}$ and $Q_{\mathrm{H}}^{\circ}$ $[12,13,15,16]$.

Let us denote $S_{\mathrm{T}}$ as the total number of avalable sites on the electrocatalyst. $S_{\mathrm{T}}$ is equal to the number of sited available for $\mathrm{H}$-adatom electrosorption $\left(S_{\mathrm{H}}^{\circ}\right)$ in the absence of potential-holding at $E_{\text {ad }}$, namely when $t_{\text {ad }}=0 . S_{\mathrm{H}}$ represents the number of sites occupied by $\mathrm{H}$-adatoms when $t_{\mathrm{ad}} \neq 0$, and $S_{\mathrm{B}}$ and $S_{\mathrm{L}}$ corresponds, respectively, to sites associated with the $\mathrm{B}$ and $\mathrm{L}$ structures of adsorbed $\mathrm{CO}$. Then,

$S_{\mathrm{T}}=S_{\mathrm{H}}+S_{\mathrm{B}}+S_{\mathrm{L}}=S_{\mathrm{H}}^{\circ}$

This assumption is valid providing that all the adsorption sites available for hydrogen adsorption are also available for the $(\mathrm{CO})_{B}$ and $(\mathrm{CO})_{L}$ species.

The charge, $Q_{\imath}$, required to electrooxidize the $i$-species adsorbed on the electrode is given by

$Q_{\imath}=n_{\imath} F S_{\imath}$ 
where $S_{t}$ is the number of sites occupied by each adsorbed species and $n_{t}$ is the number of charges per adsorption sites taking part in the electrochemical reaction. In this case, $n_{t}=1$ when $l$ is either $(\mathrm{CO})_{\mathrm{B}}$ or $\mathrm{H}$-adatom, and $n_{t}=2$ when $t$ corresponds to $(\mathrm{CO})_{\mathrm{L}}$. Then, from eqns. (5) and (6) it follows that

$\theta_{\mathrm{CO}}^{\mathrm{B}}=\left(2 Q_{\mathrm{H}}^{\circ}-2 Q_{\mathrm{H}}-Q_{\mathrm{CO}}^{\mathrm{T}}\right) / Q_{\mathrm{H}}^{\circ}$

$Q_{\mathrm{CO}}^{\mathrm{L}}=\left(Q_{\mathrm{CO}}^{\mathrm{T}}+Q_{\mathrm{H}}-Q_{\mathrm{H}}^{\circ}\right) / Q_{\mathrm{H}}^{\circ}$

and

$\theta_{\mathrm{CO}}^{\mathrm{B}}+\theta_{\mathrm{CO}}^{\mathrm{L}}=\theta_{\mathrm{CO}}^{\mathrm{T}}=1-\theta_{\mathrm{H}}$

where $\theta^{i}$ denotes the degree of surface coverage by the $t$-species.

On the basis of eqns. (7)-(9), the dependence of the different $\theta_{t}$ 's on the adsorption time $t_{\text {ad }}$ at $E_{\text {ad }}$ was evaluated (Figs. 4 and 5). The total coverage by the $\mathrm{CO}$ species obtained at a preset $t_{\text {ad }}$ value is practivally independent of $E_{\text {ad }}$ in the $0.1-0.6 \mathrm{~V}$ range (Fig. 6). This suggests that the interaction between $\mathrm{CO}$ and polycrystalline platinum is basically of a chemical-type, as suggested previously [37]. Beyond $0.6 \mathrm{~V}$ there is a remarkable decrease in the initial adsorbed $\mathrm{CO}$ charge because most of the platinum surface 1 s then covered by O-species. Consequently, the initial rate of $\mathrm{CO}$ adsorption, which is directly proportional to the degree of uncovered metal surface, diminishes. Likewise, by analogy with the results obtained

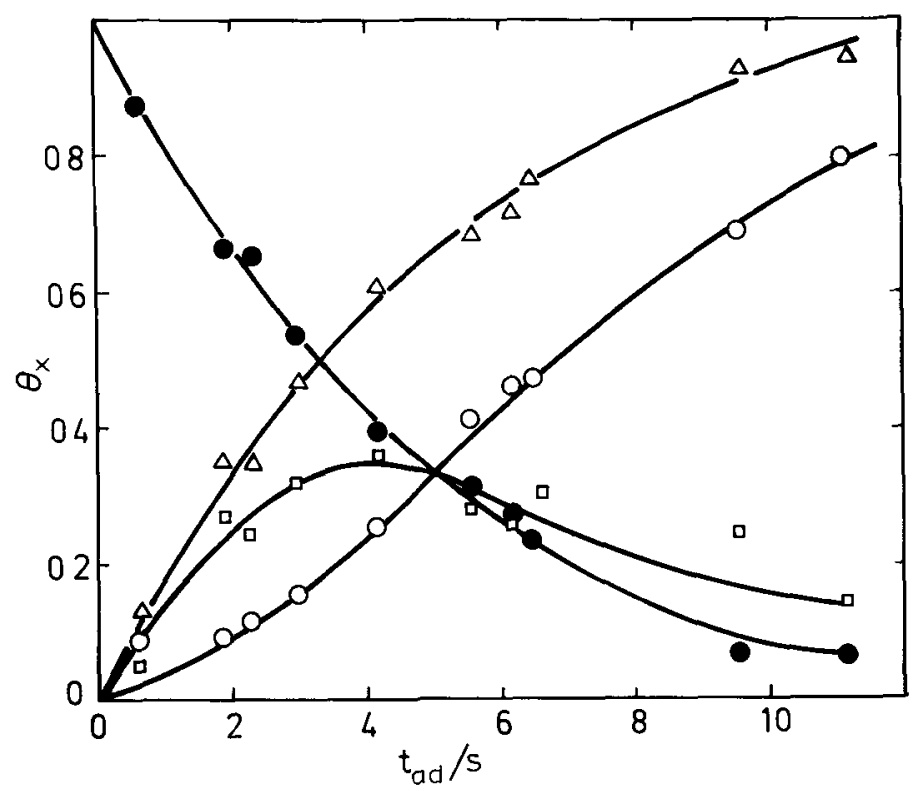

Fig 4 Dependence of the degree of surface coverage of the two adsorbed species on $t_{\text {ad }} E_{\text {ad }}=059 \mathrm{~V}$. ( $\bullet$ ) $\theta_{\mathrm{H}}$; (口) $\theta_{\mathrm{CO}}^{\mathrm{B}} ;(\mathrm{O}) \theta_{\mathrm{CO}}^{\mathrm{L}} ;(\Delta) \theta_{\mathrm{CO}}^{\mathrm{T}}=\theta_{\mathrm{CO}}^{\mathrm{B}}+\theta_{\mathrm{CO}}^{\mathrm{L}}$. 

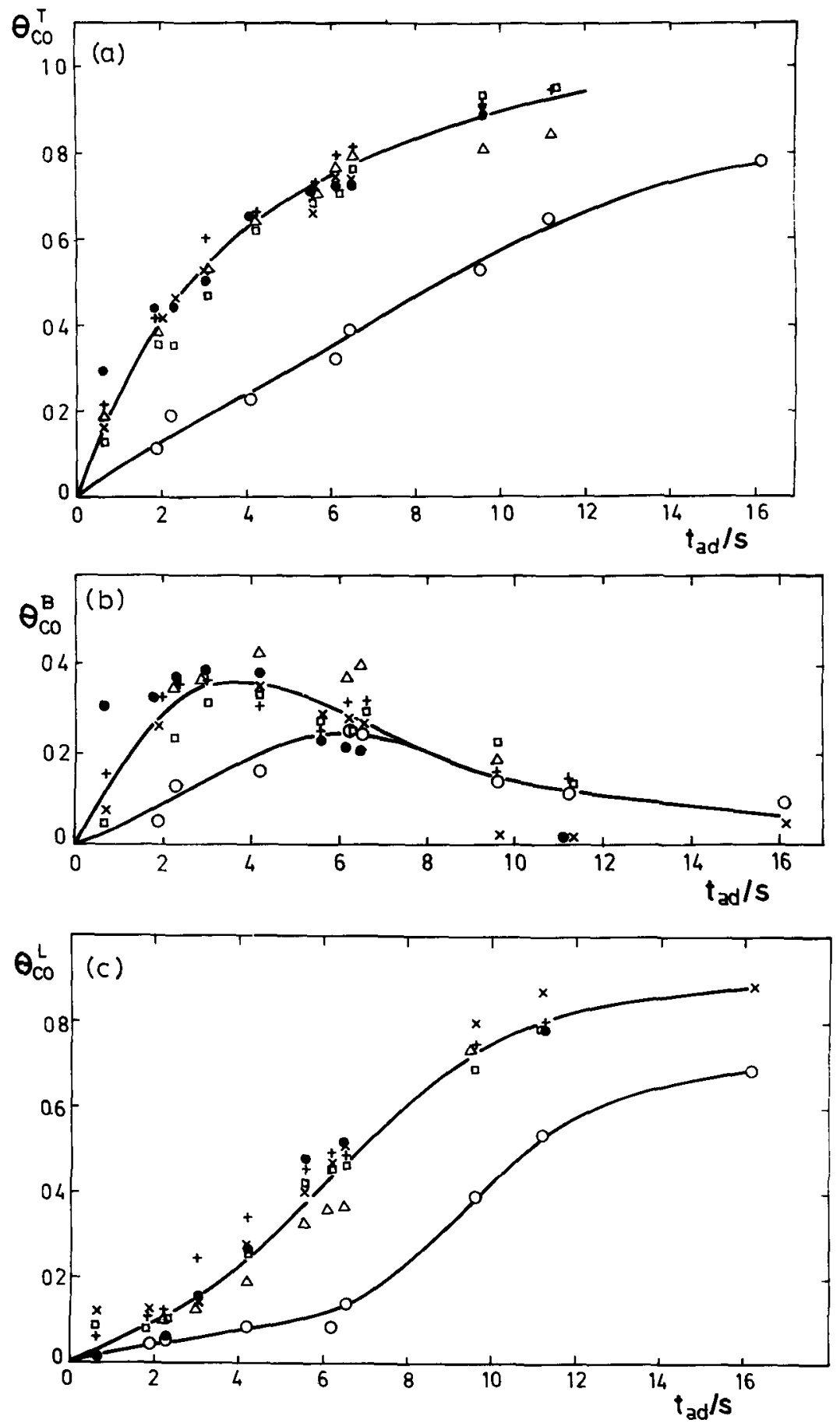

Fig 5 Dependencres of $\theta_{\mathrm{CO}}^{\mathrm{T}}(\mathrm{a}), \theta_{\mathrm{CO}}^{\mathrm{B}}(\mathrm{b})$ and $\theta_{\mathrm{CO}}^{\mathrm{L}}(\mathrm{c})$ on $t_{\mathrm{ad}}$ at different values of $E_{\mathrm{ad}} \cdot(+) E_{\mathrm{ad}}=0.12 \mathrm{~V}$;

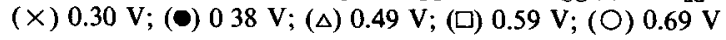




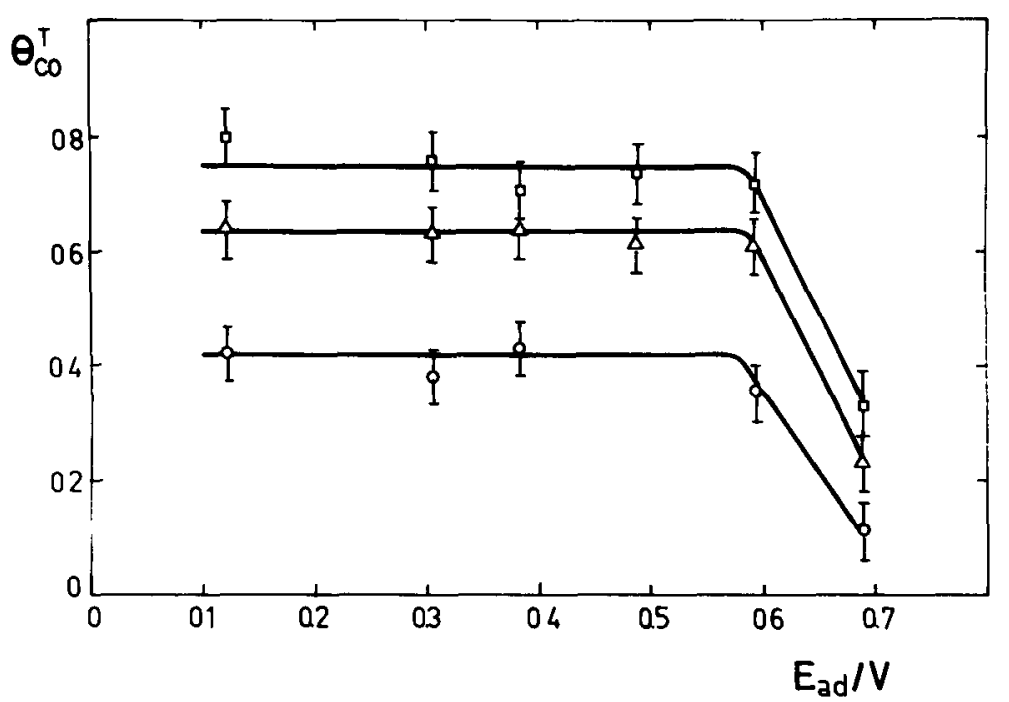

Fig 6 Influence of the adsorption potential, $E_{\text {ad }}$, on the total degree of surface coverage by $C O$. ( $\square$ ) $t_{\mathrm{ad}}=6.2 \mathrm{~s},(\Delta) t_{\mathrm{ad}}=42 \mathrm{~s},(\bigcirc) t_{\mathrm{ad}}=1.9 \mathrm{~s}$

with the platinum $/ \mathrm{CO}(\mathrm{g})$ interphase, the irreversible $\mathrm{CO}$ adsorption on platinum is hindered, unless the degree of coverage by the O-contaning species becomes sufficiently low [38]. Hence, when the platinum surface is partially covered by $\mathrm{O}$-species there is competition between the reactions

$\mathrm{Pt}+\mathrm{CO}=\mathrm{Pt}(\mathrm{CO})$

and

$\mathrm{Pt}(0)+\mathrm{CO}=\mathrm{Pt}+\mathrm{CO}_{2}$

where reaction (11) plays an important role in the whole $\mathrm{CO}$ electrooxidation potential range as revealed through the open-circuit potential decay from $E>1.2 \mathrm{~V}$ [39].

The CO electrodesorption can be regarded as a completely-irreversible electrochemical reaction, and on the assumption that two electrons per platinum site are involved in the electrodesorption of $(\mathrm{CO})_{\mathrm{L}}$ and one electron per platinum site for $(\mathrm{CO})_{B}$, linear relationships between the height of each current peak and its corresponding initial CO-coverage, $\left(\theta_{\mathrm{CO}}^{\prime}\right)_{\text {mitual }}$ (Fig. 7$)$, can be predicted according to the general expression

$i_{\mathrm{CO}}^{\prime}=\left(\beta n_{\imath} F / R T\right) \cup Q_{\mathrm{H}}^{\circ}\left[\left(\theta_{\mathrm{CO}}^{\prime}\right)_{\text {inttal }} / e\right]$

where $Q_{\mathrm{H}}^{\circ}$ is the charge associated with the electrooxidation of a hydrogen atom monolayer, and $\beta$ is the symmetry factor usually defined in electrochemical kinetics. The slopes of the straight lines are 31 and $60 \mathrm{~mA} / \mathrm{cm}^{2}$ for $(\mathrm{CO})_{B}$ and $(\mathrm{CO})_{L}$, 
respectively (Fig. 7). The ratio of the two slopes should be equal to the ratio of the $n$, values provided that both electrochemical reactions involve a similar $\beta$ value. The application of eqn. (12) is limited to a relatively small range of $v$ since at low $v$ there is interference of $\mathrm{CO}$ re-adsorption, and at large $v$ the electrooxidation of adsorbed $\mathrm{CO}$ is uncompleted [40].

To evaluate the complete potentiodynamic response of $\mathrm{CO}$-electrooxidation, a mechanistic model formally similar to that resolved to explain the peak multiplicity in thermal desorption spectra is applied [41]. The model assumes that there are two types of adsorbed species of different adsorption energy, and the possibility that one species changes into the other by jumping between different adsorption sites, which may involve a single, or two adjacent metal surface atoms. The mechanistic formalism can be put forward in terms of the adsorption and competitive adsorption processes as follows:

$\begin{array}{llll}(\mathrm{Pt})+ & \mathrm{CO} & \stackrel{k_{\mathrm{L}}}{\rightleftarrows} & (\mathrm{Pt})(\mathrm{CO})_{\mathrm{L}} \\ \left(\mathrm{Pt}_{2}\right)+\mathrm{CO} & \stackrel{k_{\mathrm{B}}}{\rightleftarrows} & \left(\mathrm{Pt}_{2}\right)(\mathrm{CO})_{\mathrm{B}} \\ \mathrm{Pt}+ & \left(\mathrm{Pt}_{2}\right)(\mathrm{CO})_{\mathrm{B}} & \stackrel{k_{\mathrm{BL}}}{\rightleftarrows} & (\mathrm{Pt})(\mathrm{CO})_{\mathrm{L}}+\left(\mathrm{Pt}_{2}\right) \\ \left(\mathrm{Pt}_{2}\right)+(\mathrm{Pt})(\mathrm{CO})_{\mathrm{L}} & \stackrel{k_{\mathrm{LB}}}{\rightleftarrows} & \left(\mathrm{Pt}_{2}\right)(\mathrm{CO})_{\mathrm{B}}+\mathrm{Pt}\end{array}$

where $k_{\mathrm{L}}, k_{\mathrm{B}}, k_{\mathrm{BL}}$ and $k_{\mathrm{LB}}$ denote the formal rate constants of the reactions in the forward direction. $(\mathrm{Pt})$ and $\left(\mathrm{Pt}_{2}\right)$ in eqns. (13)-(16) represent a single and two adjacent metal atoms at the surface which are required to form $(\mathrm{CO})_{L}$ and $(\mathrm{CO})_{B}$ species, respectively, either by direct adsorption or through motion of $\mathrm{CO}$ on the
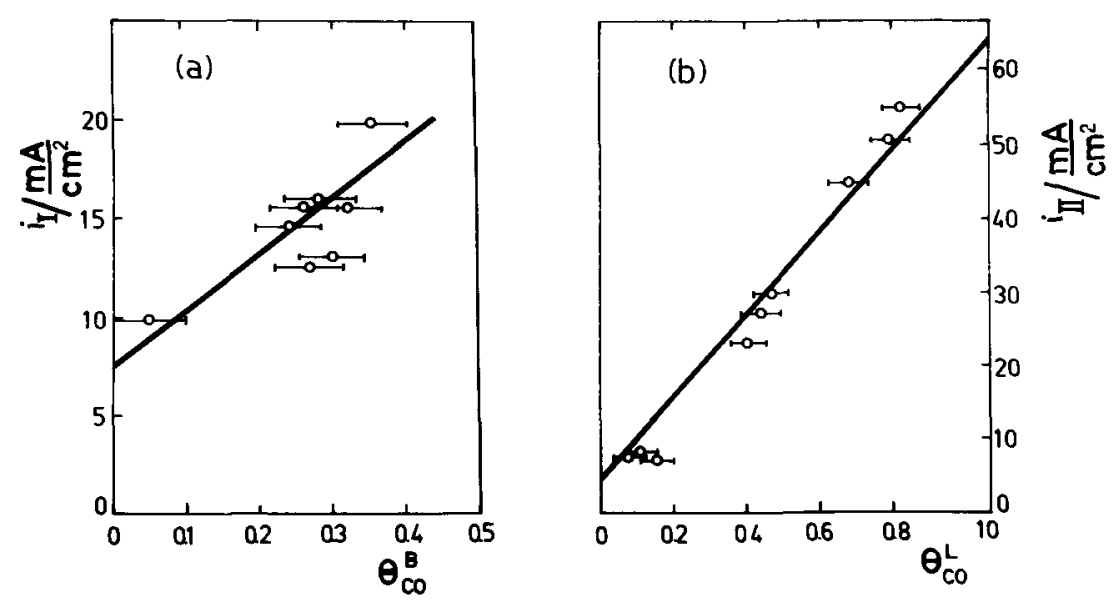

Fig. 7 Dependence of the anodic current peak heights I (a) and II (b) on $\theta_{\mathrm{CO}}^{\mathrm{B}}$ and $\theta_{\mathrm{CO}}^{\mathrm{L}}$, respectively 
surface. The rate of change of $\theta_{\mathrm{CO}}^{\mathrm{B}}$ and $\theta_{\mathrm{CO}}^{\mathrm{L}}$ during the adsorption time is given by the equations

$$
\begin{aligned}
\mathrm{d} \theta_{\mathrm{CO}}^{\mathrm{B}} / \mathrm{d} t= & k_{\mathrm{B}}\left(1-\theta_{\mathrm{CO}}^{\mathrm{B}}-\theta_{\mathrm{CO}}^{\mathrm{L}}\right)^{2} \exp \{-\alpha g(\theta)\}-k_{\mathrm{BL}} \theta_{\mathrm{CO}}^{\mathrm{B}}\left(1-\theta_{\mathrm{CO}}^{\mathrm{L}}\right) \\
& \times \exp \{(1-\alpha) g(\theta)-2 \gamma g(\theta)\} \\
\mathrm{d} \theta_{\mathrm{CO}}^{\mathrm{L}} / \mathrm{d} t= & k_{\mathrm{L}}\left(1-\theta_{\mathrm{CO}}^{\mathrm{B}}-\theta_{\mathrm{CO}}^{\mathrm{L}}\right) \exp \{-\gamma g(\theta)\}+k_{\mathrm{BL}} \theta_{\mathrm{CO}}^{\mathrm{B}}\left(1-\theta_{\mathrm{CO}}^{\mathrm{L}}\right) \\
& \times \exp \{(1-\alpha) g(\theta)-2 \gamma g(\theta)\}
\end{aligned}
$$

and

$\mathrm{d} \theta_{\mathrm{CO}}^{\mathrm{T}} / \mathrm{d} t=\mathrm{d} \theta_{\mathrm{CO}}^{\mathrm{B}} / \mathrm{d} t+\mathrm{d} \theta_{\mathrm{CO}}^{\mathrm{L}} / \mathrm{d} t$

On the basis of the induced heterogeneity model [42], $g(\theta)$ is given by the simplied equation

$g(\theta)=\frac{1}{2} f_{\mathrm{B}} \theta_{\mathrm{CO}}^{\mathrm{B}}+f_{\mathrm{L}} \theta_{\mathrm{CO}}^{\mathrm{L}}$

where the coefficient $f_{l}$ represents the variation in the heat of adsorption of the $i$-species with coverage. As the $(\mathrm{CO})_{\mathrm{B}}$ species involves two adjacent surface sites, the factor $1 / 2$ is included in the corresponding interaction term.

In eqns. (17) and (18), one admits that only reaction (15) contributes to the competitive adsorption jump, i.e. the adsorbed species changes from $(\mathrm{CO})_{B}$ to $(\mathrm{CO})_{\mathrm{L}}$. The reverse change can be neglected as it is energetically most unlikely [41].

From interpretation of eqns. (17)-(19), the experimental $\theta_{1}-t_{\text {ad }}$ curves are simulated (Fig. 8). It should be noted that although the inclusion of the $f_{\mathrm{B}}$ and $f_{\mathrm{L}}$ parameters yields the best fit of the experimental data, the same qualitative time dependence for $\theta_{\mathrm{CO}}^{\mathrm{B}}$ and $\theta_{\mathrm{CO}}^{\mathrm{L}}$ is found on assuming simple Langmuir conditions [30].

The electrooxidation current $(I)$ is given by the sum of the currents related to the following overall reactions:

$\left(\mathrm{Pt}_{2}\right)(\mathrm{CO})_{\mathrm{B}}+\mathrm{H}_{2} \mathrm{O} \stackrel{k_{\mathrm{d} \cdot \mathrm{B}}}{\rightarrow}\left(\mathrm{Pt}_{2}\right)+\mathrm{CO}_{2}+2 \mathrm{H}^{+}+2 e^{-}$

and

$$
(\mathrm{Pt})(\mathrm{CO})_{\mathrm{L}}+\mathrm{H}_{2} \mathrm{O} \stackrel{k_{\mathrm{d} \mathrm{L}}}{\rightarrow}(\mathrm{Pt})+\mathrm{CO}_{2}+2 \mathrm{H}^{+}+2 e^{-}
$$

so that

$I=I_{\mathrm{B}}+I_{\mathrm{L}}$

and

$$
I_{\imath}=A n_{t} Q_{\mathrm{H}}^{\circ}\left(-\frac{\mathrm{d} \theta_{\mathrm{CO}}^{\iota}}{\mathrm{d} t}\right)
$$




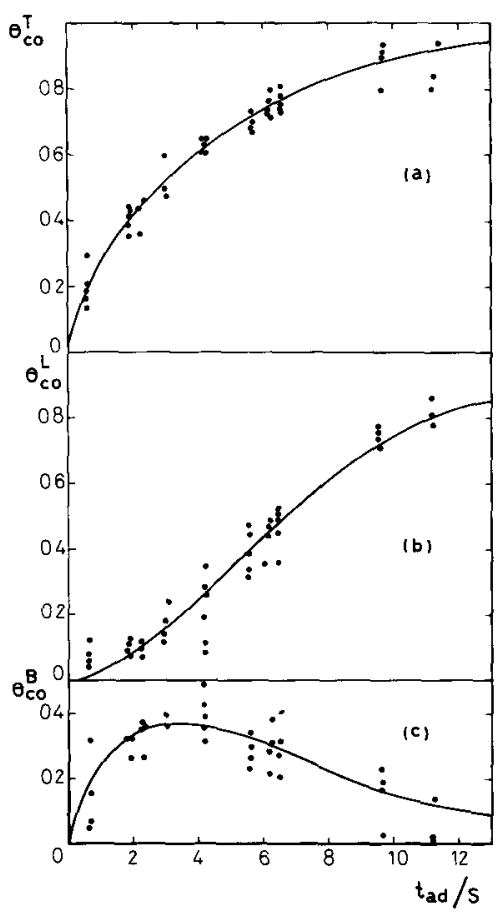

Fig 8 Theoretical curves obtained for the adsorption of $\mathrm{CO}$ at constant potential for the different species present in the surface, including Temkin-type interactions according to eqns. (17)-(20) The points are experimental data from Fig $5 . k_{\mathrm{B}}=5 \times 10^{-1} \mathrm{~s}^{-1} ; k_{\mathrm{L}}=1 \times 10^{-6} \mathrm{~s}^{-1}, k_{\mathrm{BL}}=25 \times 10^{-1} \mathrm{~s}^{-1}, f_{\mathrm{B}}=4$, $f_{\mathrm{L}}=-5$. (a) $(\mathrm{CO})_{\mathrm{B}}+(\mathrm{CO})_{\mathrm{L}}$ species, (b) $(\mathrm{CO})_{\mathrm{L}}$ species; (c) $(\mathrm{CO})_{\mathrm{B}}$ species

where $A$ is the electrode area. The electrodesorption rate equations for the $\mathrm{B}$ and $\mathrm{L}$ species are

$$
\begin{aligned}
& -\frac{\mathrm{d} \theta_{\mathrm{CO}}^{\mathrm{B}}}{\mathrm{d} t}=k_{\mathrm{d}, \mathrm{B}} \theta_{\mathrm{CO}}^{\mathrm{B}} \exp \left\{\beta F\left(E_{1}+v t\right) / R T\right\} \exp \{-(1-\alpha) g(\theta)\} \\
& -\frac{\mathrm{d} \theta_{\mathrm{CO}}^{\mathrm{L}}}{\mathrm{d} t}=k_{\mathrm{d}, \mathrm{L}} \theta_{\mathrm{CO}}^{\mathrm{L}} \exp \left\{\beta F\left(E_{\mathrm{L}}+v t\right) / R T\right\} \exp \{-(1-\gamma) g(\theta)\}
\end{aligned}
$$

where $k_{\mathrm{d}, l}$ is the formal rate constant for the desorption of the $l$-species, and $E_{1}$ is the initial potential.

By solving eqns. (23)-(26) for the initial values of $\theta_{\mathrm{CO}}^{\mathrm{B}}$ and $\theta_{\mathrm{CO}}^{\mathrm{L}}$, the theoretical $E / I$ profiles are computed [43]. It should be noted that three out of the five adjustable parameters are required for the calculation. The initial $\theta_{\mathrm{CO}}^{\mathrm{L}}$ and $\theta_{\mathrm{CO}}^{\mathrm{B}}$ values are derived from the experiments, and the Temkin factors are the same as those used in calculating the $\theta_{l} /$ time plots in the potential independent adsorption range (Fig. 8). Then, in this case, the only adjustable parameters are the rate constants $k_{\mathrm{B}}$ and $k_{\mathrm{d}, \mathrm{L}}$. Furthermore, the contribution of the O-electroadsorption current from the 
blank appears as an additive term in the overall electrooxidation current (Fig. 9). The fitting of the experimental and theoretical $E / I$ profiles is reasonably good. However, the experimental display lags the theoretical display (Fig. 9) at the negative potential side. This suggests that the model works reasonably well when the degree of surface coverage for the different species is in the intermediate range. Apparently, the initiation of the electrooxidation process involves an induction period, which is necessary to create an adequate configuration of particles in order for the reaction to proceed. This correlates with previously reported observations showing that the oxidation of $\mathrm{CO}$ not adjacent to a free site is completely hindered [12]. On the other hand, when only a small fraction of the surface sites are involved in normal adsorbed $\mathrm{CO}$ electrooxidation, the $E / I$ profile is strongly dependent on the complex O-electrosorption process; therefore, the latter must influence the former process. These two effects are not taken into account in the simple reaction schemes discussed above. However, these discrepancies do not preclude the estimation of the most likely apparent specific rate constants of reactions (21) and (22), which at $23^{\circ} \mathrm{C}$ are $k_{\mathrm{d}, \mathrm{B}}=5 \times 10^{-6} \mathrm{~s}^{-1}$ and $k_{\mathrm{d}, \mathrm{L}}=1 \times 10^{-6} \mathrm{~s}^{-1}$, respectively. The computational work, however, does not preclude that other satisfactory fitting may be obtained with other sets of kinetic parameters. The proposed reaction mechanism for the electrochemical oxidation of chemisorbed $\mathrm{CO}$ has some similarities to that proposed for the catalysed gas-phase oxidation of $\mathrm{CO}$ by oxygen [37]. The adsorbed forms used in the reaction pattern correlate with the two types of $\mathrm{CO}$-adsorbed

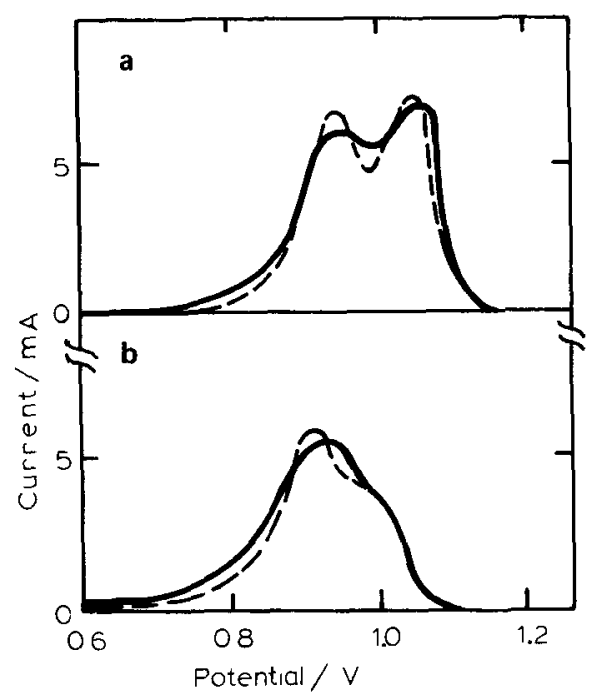

Fig 9. Comparison of the theoretical potentiodynamic $E / I$ profiles calculated from eqns (23)-(26) with the experimental profiles for the electrooxidation of adsorbed CO. ( $-\longrightarrow$ ) Calculated curve; (- . - - -) experimental curve including correction from the blank. $k_{\mathrm{d}, \mathrm{B}}=5 \times 10^{-5} \mathrm{~s}^{-1} ; k_{\mathrm{d} . \mathrm{L}}=1 \times 10^{-} 8 \mathrm{u} 5 \mathrm{~s}^{-1}$; $f_{\mathrm{B}}=4$ and $f_{\mathrm{L}}=-5 . \alpha=\gamma=0.5, v=10 \mathrm{~V} / \mathrm{s}$, electrode area $=0.68 \mathrm{~cm}^{2}$. (a) $\left(\theta_{\mathrm{CO}}^{\mathrm{B}}\right)_{1 \mathrm{nutual}}=0.27 ;\left(\theta_{\mathrm{Co}}^{\mathrm{L}}\right)_{\text {Imtual }}$ $=0.22$, (b) $\left(\theta_{\mathrm{CO}}^{\mathrm{B}}\right)_{\text {initual }}=0.31,\left(\theta_{\mathrm{Co}}^{\mathrm{L}}\right)_{\text {initial }}=0.12$. 
species derived from different studies of platinum/ $\mathrm{CO}(\mathrm{g})$ interphases, such as flash-desorption spectra, LEED and the work function of $\mathrm{CO}$ from platinum (111) $[6,7]$, and the kinetics of $\mathrm{CO}$ adsorption using $\mathrm{CO}$ labelled with ${ }^{14} \mathrm{C}[44]$ and in situ IR data [22].

The results of the computed reaction pattern explain the observations previously made on the ageing effect of the conventional CO-chemisorbed electrooxidation current peak becoming more symmetric and thinning on ageing [12,13], as well as the difficulty in elucidating the kinetics of the anodic oxidation of $\mathrm{CO}$ chemisorbed on aged platinized platinum [10]. The present data also support the possible existence of a mobile $\mathrm{CO}$-adsorbed film at relatively low surface coverages with a predominant bridged-type adsorbate [45].

\section{ACKNOWLEDGEMENT}

This work is part of the research programme of the Electrochemistry Division of INIFTA, sponsored by the Universidad Nacional de La Plata, the Consejo Nacional de Investigaciones Cientificas y Técnicas and the Comision de Investigaciones Crentíficas de la Provincia de Buenos Aires.

\section{REFERENCES}

1 M.W. Bretter, Electrochemical Processes in Fuel Cells, Springer Verlag, New York, 1969, Chs. 6, 9 and 10.

2 M W. Bretter in J O'M. Bockns and B.E. Conway (Eds), Modern Aspects of Electrochemistry, Vol. 10, Plenum Press, New York, 1975, Ch. 3.

3 J.P. Randin in A.J Bard (Ed.), The Encyclopedia of the Electrochemistry of the Elements, Vol. 7, Marcel Dekker, New York, 1976, Ch 1.

4 R.P. Eischens and W. Pliskın, Adv. Catal , 10 (1954) 18

5 H. Hopster and H. Ibach, Surf. ScI, 77 (1978) 109

6 R N. McCabe and L D. Schmidt, Surf. Sc1, 65 (1977) 189

7 G. Ertl, M Neumann and K.M Strett, Surf Sc1., 64 (1977) 393.

8 S A. Bılmes, N R de Tacconı and A J. Arvia, J. Electrochem. Soc., 127 (1980) 2184.

9 R.O. Lezna, N.R. de Tacconı and A.J. Arvía, J. Electrochem. Soc, 126 (1979) 2140.

10 M.W. Bretter, J Electroanal. Chem, 101 (1979) 329.

11 M.E Folquer, J O. Zerbino, N.R. de Tacconı and A.J. Arvía, J. Electrochem. Soc., 126 (1979) 592.

12 S. Gilman, J Phys Chem., 66 (1962) 2657

13 S. Gilman, J. Phys Chem, 67 (1963) 78

14 A.B. Fasman, G.L. Padyukova and D.V. Sokolovsku, Dokl Akad Nauk SSSR, 4 (1963) 856

15 S. Gilman, J Phys Chem., 67 (1963) 1898

16 S. Gilman, J Phys. Chem., 68 (1964) 70

17 M.W Bretter, J. Phys. Chem., 72 (1968) 1305

18 M.W. Bretter, J Electroanal. Chem., 115 (1980) 45

19 M.W Breiter, J. Electroanal. Chem., 65 (1975) 623.

20 M.W Bretter, J. Electroanal. Chem., 127 (1981) 157.

21 K. Kunimatsu, J. Electroanal. Chem., 140 (1982) 205.

22 B. Beden, A. Bewick, K. Kunımatsu and C. Lamy, J. Electroanal Chem., 142 (1982) 345

23 J.W. Russell, M. Soverson, K Scanlon, J. Overend and A. Bewick, J. Phys Chem., 87 (1983) 293. 
24 B.E. Conway, H. Angersteın-Kozlowska, W.B A Sharp and E.E Cnddle. Anal Chem, 45 (1973) 1331.

25 P Stonehart, Electrochim Acta, 15 (1970) 1853

26 I. Bett, K Kınoshıta, K Routsies and P Stonehart, J. Catal, 29 (1973) 160.

27 A.B Fasman and G.L. Padyukova. Elektrokhımiya, 10 (1974) 39.

$28 \mathrm{C}$ McCallum and D. Pletcher, J. Electroanal. Chem, 70 (1976) 277.

29 G. Kohlmayr and P Stonehart, Electrochim. Acta, 18 (1973) 211.

30 S.A Bılmes, N.R de Tacconı and A.J Arvia, Proceedıngs of the Spring Meetıng of the Electrochemıcal Society, Minneapolıs, May 1981, The Electrochemical Society, Pennington, 1982, p. 276.

$31 \mathrm{O}$ Wolter, M C. Giordano, J. Heitbaum and W. Vielstich in ref 30, p. 235.

32 S.B Brummer and K Cahill, Discuss. Faraday Soc, 45 (1968) 67

33 F G. Will, J Electrochem. Soc, 112 (1965) 451

34 P. Stonehart, Electrochum Acta, 18 (1973) 63

35 F C Will and C A Knorr, Z Elektrochem. 64 (1960) 258, R. Woods, J. Electroanal. Chem, 49 (1974) 217.

36 P.R. Norton, J W Goodale and F B Selkırk, Surf Scı. 83 (1979) 189, A.M Bradshaw, Surf. Scı. 80 (1979) 215.

37 P. Stonehart, J. Electroanal. Chem., 15 (1967) 239

38 P.R. Norton, D.K Creber and J W. Goodale in G. Ertl (Ed.) Proceedings of the 4th International Conference on Solid Surfaces and the 3rd European Conference on Surface Science, Cannes, September 1980

39 S.A. B1lmes, N.R. de Tacconı and A.J Arvia, to be published.

$40 \mathrm{C}$ Gossner and E. Mizera, J Electroanal. Chem, 98 (1979) 37

41 S B Whitehouse and P. Jewsbury, Appl Phys, 19 (1975) 387

42 B.E Conway and E Gilead, Trans Faraday Soc., 58 (1962) 2493.

43 S.A. Bilmes, Doctoral Thesis, University of Buenos Aires (1982).

44 A Czerwınskı and J Sobkowskı, J Electroanal. Chem, 91 (1978) 47.

45 S.B Brummer and J I Ford, J. Phys. Chem 69 (1965) 1355. 